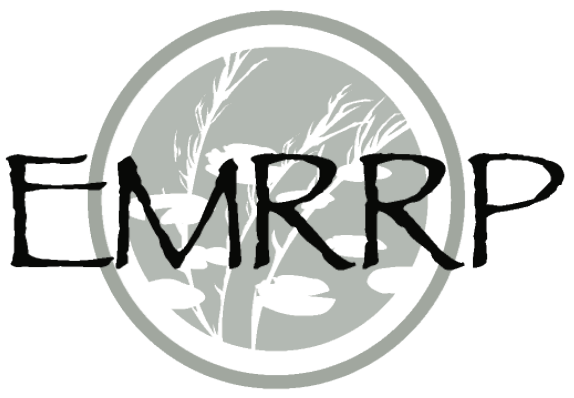

\title{
Habitat Provision Associated with Environmental Flows
}

by Natalia V. Bhattacharjee ${ }^{1}$, Joshua R. Willis ${ }^{2}$, E. W. Tollner ${ }^{3}$, and S. Kyle McKay ${ }^{4}$

OVERVIEW: A comprehensive analysis of environmental flows, the amount, timing and quality of flow regimes, represents a key step in ensuring adequate water availability to meet increasing human needs while minimizing adverse impacts on aquatic ecosystems. This study investigates how several modeled instream flow and water withdrawal scenarios affect habitat provision in the Middle Oconee River near Athens, Georgia. Historical discharge data are coupled with water withdrawal simulations for each withdrawal scheme to examine trade-offs between ecological and social outcomes (i.e., habitat provision and water withdrawal, respectively). Hydraulic models are applied to translate hydrologic simulations into habitat suitability for the following three generic habitat types: shallow-fast, deep-fast, and shallow-slow. The availability and distribution of habitats are analyzed with respect to increasing water withdrawal rates. Finally, the utility of deterministic modeling approaches based on long-term average conditions relative to stochastic modeling approaches using frequency-weighted outcomes are compared. The analytical methodology and approach set forth in this technical note (TN) may be easily adapted to inform environmental flow analyses at other study sites.

INTRODUCTION: Human society, culture, and economy are vitally dependent upon freshwater ecosystems; however, these systems are becoming increasingly compromised (Strayer and Dudgeon 2010). For instance, human uses capture more than $50 \%$ of available freshwater runoff, and upwards of 1,000,000 dams fragment river systems globally (Jackson et al. 2001). These factors, plus many others, have led to rivers becoming the earth's most damaged ecosystems, losing species at greater rates than terrestrial and marine ecosystems (Dudgeon et al. 2006). Accordingly, sustainable strategies for river management are needed which balance aquatic ecosystem integrity and human livelihoods that rely on them, and significant research and management has been devoted to the subject. Environmental flows provide at least a partial solution to these freshwater systems management challenges. In the 2007 "Brisbane Declaration," 5 over 750 scientists, engineers, and lawmakers from around the world defined environmental flows as "the quantity, timing, and quality of water flows required to sustain freshwater and estuarine ecosystems and the human livelihoods and well-being that depend on these ecosystems."

1 University of Georgia, Athens, GA, shimnata@uga.edu

2 University of Georgia, Athens, GA, jwill306@uga.edu

3 University of Georgia, Athens, GA, btollner@engr.uga.edu

4 U.S. Army Engineer Research and Development Center (ERDC), Environmental Laboratory (EL), New York, NY, kyle.mckay@usace.army.mil

5 https://www.conservationgateway.org/Documents/Brisbane-Declaration-English.pdf 
A wide variety of strategies exists for identifying environmental flow targets and thresholds, which have been reviewed elsewhere (e.g., Jowett 1997, Tharme 2003, McKay 2013). While more complex methods exist, simple hydrologic thresholds remain extremely common in practice. Hydrologic indices calculated from historically observed discharge data at daily, monthly, or annual time-scales typically form the basis for these operational rules. Minimum flow levels set a river discharge (or stage) below which water may not be withdrawn, and these techniques are extremely common in setting regulatory thresholds at annual or monthly timescales. Percent of flow methods represent a second simple environmental flow technique, in which a percent deviation from an upstream discharge rate guides withdrawal amounts or reservoir operations. Percent of flow methods (i.e., sustainability boundaries) are gaining popularity, in part, due to straightforward operational goals and the capacity to preserve natural variability in flow regimes (Richter 2010; Richter et al. 2011).

Rivers are extremely dynamic systems, and flow regimes often exhibit many sources of variability both within a year (e.g., seasonal periodicity) and between years (e.g., wet and dry years) (Sabo and Post 2008). Accordingly, a growing body of researchers have pressed river managers to not only manage variability, but manage for variability (Arthington et al. 2006; Poff 2009; McKay et al. 2016). However, environmental flow thresholds are often set based on "typical" river flow levels (i.e., long-term averages or central tendencies). Historically, river engineers have struggled to cope with the challenges of what discharges to use in design and management, and a common method for incorporating the magnitude and frequency of events is "effectiveness analysis" (Wolman and Miller 1960). Recently, this family of techniques has been adapted for ecological applications in streams (Doyle et al. 2005; Wheatcroft et al. 2010), including environmental flow analyses (McKay et al. 2016).

The purpose of this TN is two-fold. First, a set of methods for comparing simple environmental flow alternatives and developing flow thresholds is demonstrated, which applies the common approach of habitat analyses. Second, the role of variability in setting flow management thresholds by comparing environmental flow recommendations developed using typical river levels (i.e., long-term averages) with those developed using a frequency-weighted approach (i.e., effectiveness analysis) is examined. The analysis and findings of this TN focus on a case study in the Middle Oconee River near Athens, Georgia, but the techniques applied are transferrable to applications elsewhere.

MIDDLE OCONEE RIVER, GEORGIA: As a result of growing human population and economic development in northeast Georgia, surface water withdrawal is projected to increase until at least 2050 (Northeast Georgia Plan 2011; Upper Oconee Regional Water Plan 2011). The Middle Oconee River is a sixth-order tributary of the Altamaha River located in northeast Georgia with a drainage area of $398 \mathrm{mi}^{2}$. Rapid development in the region has increased municipal water demand, and as a response, Bear Creek Reservoir was constructed in 2002 to meet municipal water needs of four surrounding counties. Bear Creek Reservoir is a pumpstorage reservoir located on a tributary, but filled with water from the Middle Oconee River. Since 1938, the U.S. Geological Survey (USGS) has operated a long-term streamflow monitoring station downstream of the intake on the Middle Oconee River (Gage number 02217500) (Figure 1). The four-county water authority is permitted to withdraw a maximum of 60 million gallons per day (MGD) (Georgia EPD Permit Number 078-0304-05) subject to 
meeting minimum flow criteria. Currently, the reservoir typically withdraws less than 20 MGD (Campana et al. 2012), but the permitted rate represents a substantial portion of river discharge $(60 \mathrm{MGD}=92.8 \mathrm{cfs})$, particularly during the late summer months when flow rates are lowest (September mean $=237 \mathrm{cfs}$ translates to a maximum withdrawal of $39 \%$ of discharge). Thus, this system provides a unique long-term flow data set with minimal flow alteration (i.e., few upstream withdrawals and no major impoundments) including an opportunity to examine the effects of flow management actions for a pump-storage configuration, which are becoming more common in the region.

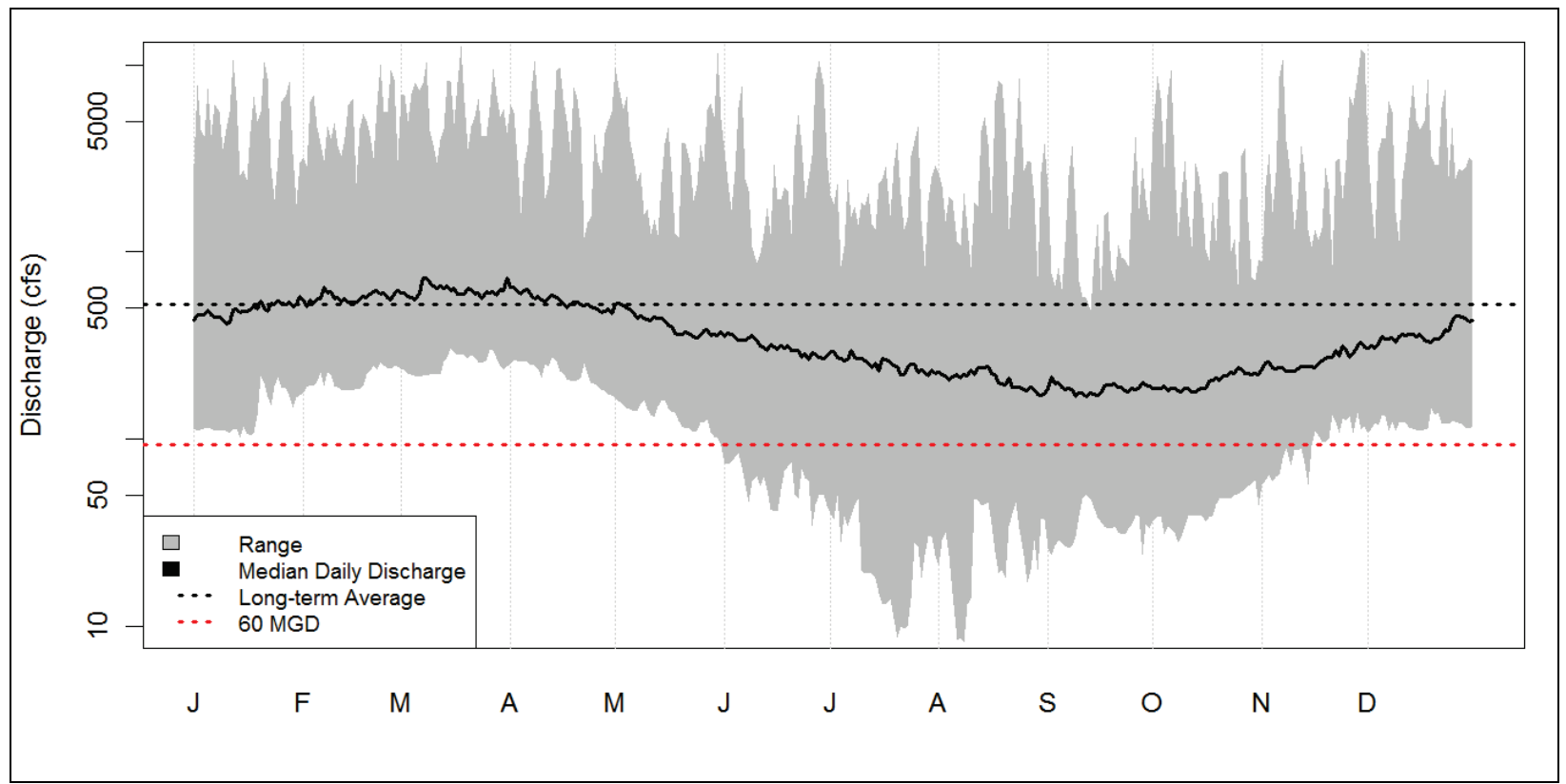

Figure 1. Long-term, minimally altered hydrograph (1938-1997) on the Middle Oconee River near Athens, Georgia USGS 02217500. The shaded area represents the lowest and highest discharge observed on each day of the year for the entire period of record, the solid black line represents the daily median for the period of record, the dashed black line represents the average annual daily mean for the period of record, and the red dashed line represents the maximum permitted pump capacity for Bear Creek Reservoir (92.8 cfs).

METHODS: Here, the ecological effects of different environmental flow thresholds for the Middle Oconee River are examined. First, hydrologic alteration associated with three different withdrawal schemes is simulated. Second, a hydraulic model to translate changes in discharge into changes in velocity and depth regimes (ecologically relevant habitat variables) is constructed. Third, generalized habitat criteria are applied to quantify changes in the general habitat composition in the Middle Oconee River as a result of municipal water withdrawal.

Flow Management. Continuous daily average discharge records are available from 1938 to present. A period of analysis from 1938-1997 was used, which represents a minimally altered flow regime and approximates the data available at the time of permit application. Over this 60 year period, daily mean, median, minimum, and maximum discharges were $521,350,8.2$, and $12,600 \mathrm{cfs}$, respectively. Four scenarios of municipal water withdrawal and environmental flow requirements were simulated to represent the same 60-year period (304 total simulations, additional detail on scenarios provided in McKay 2015): 
1. Unaltered (one simulation): A reference condition without withdrawal defined the best attainable ecological condition and served as a point of relative comparison for other scenarios.

2. Annual minimum flow (AMF): This method assigns a single, year-round flow threshold below which water may not be withdrawn. The minimum flow threshold was varied from $0-1,000 \mathrm{cfs}$, in $10 \mathrm{cfs}$ increments (101 simulations).

3. Monthly minimum flow (MMF): This method assigns a monthly-varied flow threshold below which water may not be withdrawn, which incorporates elements of flow timing not captured in annual minimum flows. Flow thresholds were varied in 101 intervals (101 simulations) from the minimum observed monthly-averaged flow to the maximum observed monthly-averaged flow for the 60-year record for each of the 12 months.

4. Percent of flow (POF): This method withdraws a specified percentage of the unaltered discharge, which was varied from $0-50 \%$ by $0.5 \%$ (101 simulations).

For each simulation, the unaltered hydrograph was modified for the entire 60-year observational period (i.e., 1938-1997). Water was withdrawn at a maximum rate of 60 MGD as constrained by existing pump capacity. Although previously acknowledged as operational constraints (Vogel et al. 2007), neither reservoir volume limitations nor increased water treatment costs due to turbidity of high flows were included in this analysis. Each simulation produced a 60 -year record of daily river discharge and daily water withdrawal, which are subsequently used in habitat trade-off analyses. Ad hoc numerical models were developed in the $\mathrm{R}$ statistical software ( $\mathrm{R}$ Development Core Team 2012), the code is available from authors upon request.

Hydraulic Modeling. While hydrologic alteration is a common surrogate for ecological integrity, habitat analyses were applied here to converted hydrologic change into hydraulic variables (e.g., velocity and depth at steady state), which are often more ecologically relevant. Here, the USACE Hydrologic Engineering Center's River Analysis System (HEC-RAS version 4.1.0) was applied to assess channel hydraulics along with the accompanying HEC-GeoRAS (Version 10.1), which facilitates geospatially explicit analyses in ArcGIS ${ }^{\circledR}$ (Brunner 2001).

The study area encompasses a small reach near Ben Burton Park in Athens, Georgia, which is approximately $1200 \mathrm{ft}$ long and 150-200 ft wide. Elevation data were compiled from three sources to generate an integrated digital elevation model (DEM) of the topography and bathymetry of the study site (Figure 2). High-resolution Light Detection and Ranging (LiDAR) data were obtained from local government, ${ }^{1}$ which provided a $4 \mathrm{ft} \mathrm{X} 4 \mathrm{ft}$ gridded DEM for bank and floodplain zones. Eleven cross-sectional surveys were collected at the site in June-July 2013 to better characterize underwater bathymetry, a common gap in LiDAR measurements. ${ }^{2}$ Ten additional cross sections were collected in November-December 2015 to fill gaps in surveyed cross section data. To validate consistency between the different survey teams, four of the cross sections collected in 2013 and 2015 were surveyed by both survey teams. All cross-sectional surveys included points in bank and floodplain zones to assist in merging with the LiDAR data. The inverse distance-weighting tool in ArcMap was used to interpolate between elevation data gaps to form a gridded elevation layer for the LiDAR data and both sets of field surveys. All three data sets were stitched together, with LiDAR data used for floodplain zones (i.e., above the

1 Personal Communication, Mary R. Martin, GIS Administrator, Athens-Clarke County Planning Department. 2 Personal Communication, Dr. Bruce Pruitt, USACE Environmental Laboratory. 
top of bank elevation of $570 \mathrm{ft}$ ) and survey data used for channel and bank zones (i.e., below the top of bank elevation of $570 \mathrm{ft}$ ). The combined raster data were converted to a triangular irregular network (TIN) as the primary input to HEC-RAS.

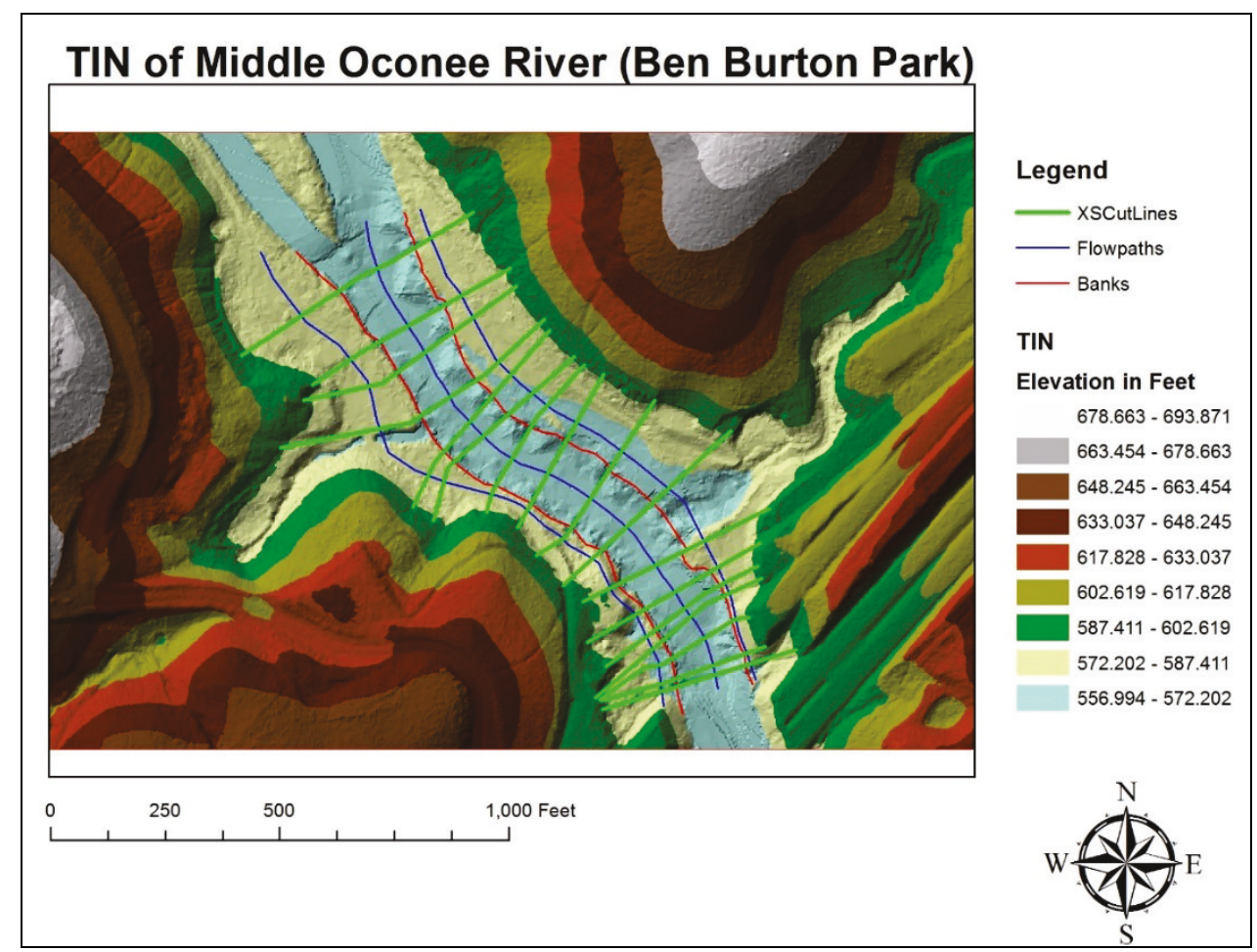

Figure 2. Topographic and bathymetric map of the study reach on the Middle Oconee River near Athens, GA. Surveyed cross sections are shown in green, primary main channel and floodplain flow paths in blue (derived from HEC-GeoRAS), and top of bank in red.

In addition to terrain, HEC-RAS requires user-inputs related to flow paths, channel slope, and channel roughness. Flow paths were demarcated using HEC-GeoRAS. Following standard convention, floodplain flow paths were defined as the center of mass between the top of the bank and the extent of the floodplain (roughly $1 / 3$ of the distance from the banks and $2 / 3$ from the floodplain extent). To estimate channel slope, thalweg measurements in each cross section (i.e., the deepest point) were plotted against longitudinal distance downstream. The slope of the best fit, linear regression of these data were used as the channel slope, $0.00245 \mathrm{ft} / \mathrm{ft}$. Channel roughness (Manning's $n$ ) was estimated through iterative calibration. A starting Manning's $n$ value was selected from standard tabulated values for the channel and floodplain environments in the study site (i.e., Tables 5-5 and 5-6 in Chow 1959). Roughness values were then iteratively adjusted based on the following two sets of observed water surfaces: 1) water surface elevations during low flow survey periods, and 2) a December 2015 high flow that deposited fresh alluvial sand as an indicator of water surface elevation. This process resulted in four distinct values of Manning's n: 0.065 for the open, moderately vegetated left floodplain, 0.070 for the more densely vegetated right floodplain, 0.025 for sandy portions of the channel, and 0.040 for rocky or "shoaly" portions of the channel. 
Habitat Analysis. The Middle Oconee River has high biodiversity with over 27 species of native fish caught at the study site. ${ }^{1}$ For comparison, the entire Colorado River Basin has fewer than 30 species of native fish. The biodiversity of southeastern streams makes a species-byspecies habitat assessment prohibitively difficult and impractical (Bowen et al. 1998). To fill this gap, Freeman et al. (1997) developed generalized habitat suitability criteria for nine fish species by including depth, velocity, substrata type and cover. This study addressed three key types of habitat for local taxa, which are comparable to assemblages observed by Freeman et al. (1997), with the following accompanying criteria for depth and velocity: shallow-fast, deep-fast, and shallow-slow (Table 1).

\begin{tabular}{|c|c|c|c|}
\hline Key Habitat & River Depth & Flow Velocity & Representative Taxa \\
\hline 1. Shallow - Fast & $\leq 35 \mathrm{~cm}(\leq 1.15 \mathrm{ft})$ & $\geq 55 \mathrm{~cm} / \mathrm{s}(\geq 1.8 \mathrm{ft} / \mathrm{s})$ & $\begin{array}{l}\text { Nocomis leptocephalus } \\
\text { (bluehead chub) } \\
\text { Notropis hudsonius (spottail } \\
\text { shiner) }\end{array}$ \\
\hline 2. Deep - Fast & $\geq 35 \mathrm{~cm}(\geq 1.15 \mathrm{ft})$ & $>45 \mathrm{~cm} / \mathrm{s}(>1.48 \mathrm{ft} / \mathrm{s})$ & $\begin{array}{l}\text { Micropterus Salmoides } \\
\text { (largemouth bass) }\end{array}$ \\
\hline 3. Shallow - Slow & $<35 \mathrm{~cm}(<1.15 \mathrm{ft})$ & $<35 \mathrm{~cm} / \mathrm{s}(<1.15 \mathrm{ft} / \mathrm{s})$ & $\begin{array}{l}\text { Lepomis spp. } \\
\text { (bluegill and sunfish) }\end{array}$ \\
\hline
\end{tabular}

Using these criteria, habitat suitability was predicted over 79 incremental values of river discharge: 10-200 cfs (by $10 \mathrm{cfs}$ ), 200-1,000 cfs (by $20 \mathrm{cfs}$ ), and 1,000-20,000 cfs (by 1,000 cfs). For each discharge, HEC-RAS was executed under steady-state conditions, and spatially explicit velocity and depth distributions were generated. A Python script was then applied in ArcGIS to calculate wetted usable area (i.e., total available habitat) and suitability for each habitat type for each of the 79 discharge simulations (Example shown in Figure 3).

Each of the 304 environmental flow regimes were then assessed based on habitat suitability. First, aerial extent of the four habitat types (shallow-fast, deep-fast, shallow-slow, and total wetted area) was mapped at the average annual discharge for each of the 304 flow regimes. This provides an overall assessment of the rate of decline in available habitat with increasing water withdrawal, on average. Second, magnitude-frequency analysis was used to estimate the amount of habitat across the entire range of the flow regime (Figure 4). For each environmental flow scenario, a frequency distribution of all discharge values was obtained (frequency curve in Figure 4). A habitat rating curve was developed from the HEC-RAS simulations for all four habitat types. The product of the amount of habitat (i.e., magnitude) and probability of occurrence (i.e., frequency) provides a relative measure of the time-weighted amount of habitat (i.e., the effectiveness curve in Figure 4). The area under this curve is the total amount of a given habitat type provided by the entire flow regime over the 60-year simulation period, which provides a more robust measure of habitat than habitat quantity at the average annual discharge.

1 Personal Communication, Dr. Mary Freeman, U.S. Geological Survey. 


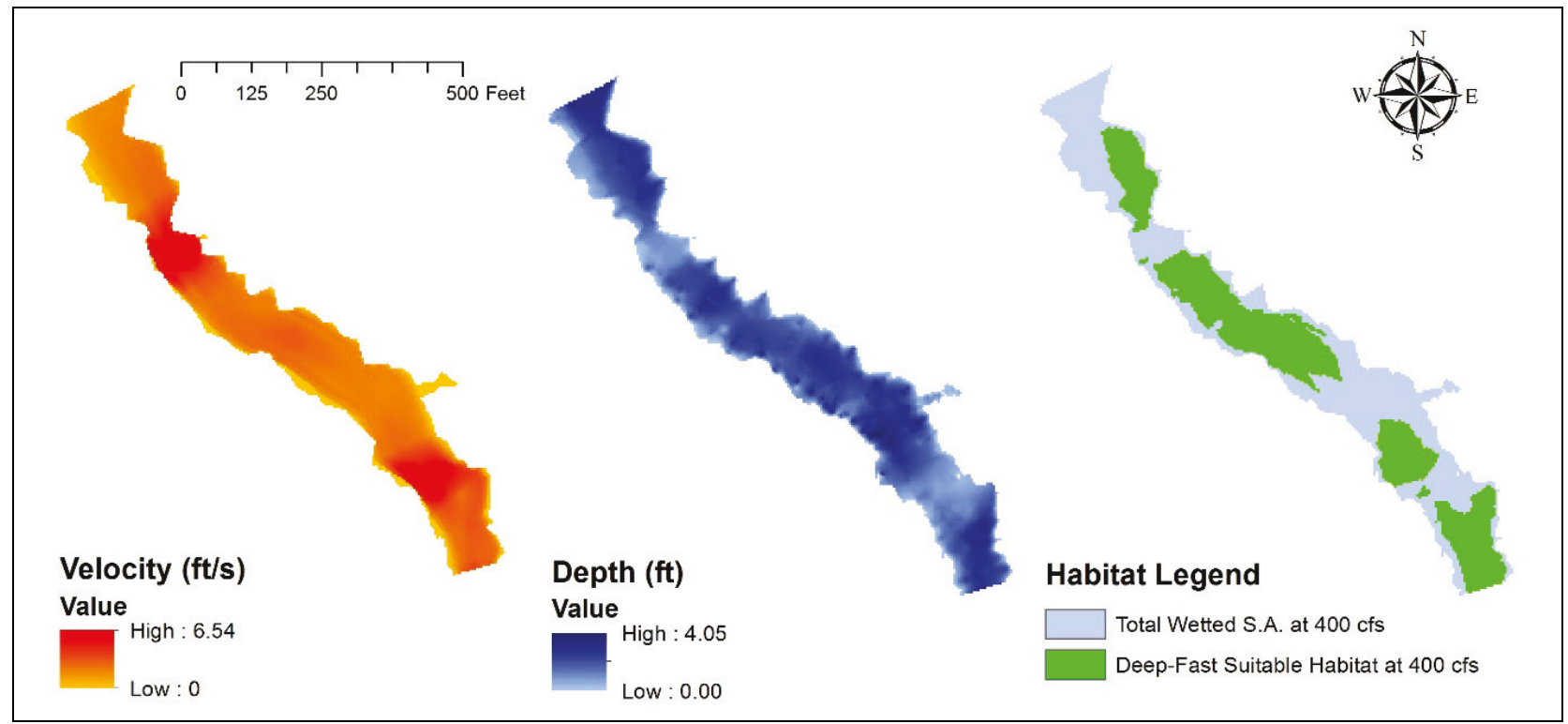

Figure 3. Example of spatially explicit outputs for hydraulic and habitat models at $400 \mathrm{cfs}$ : (left) velocity, (center) depth, and (right) deep-fast habitat suitability.

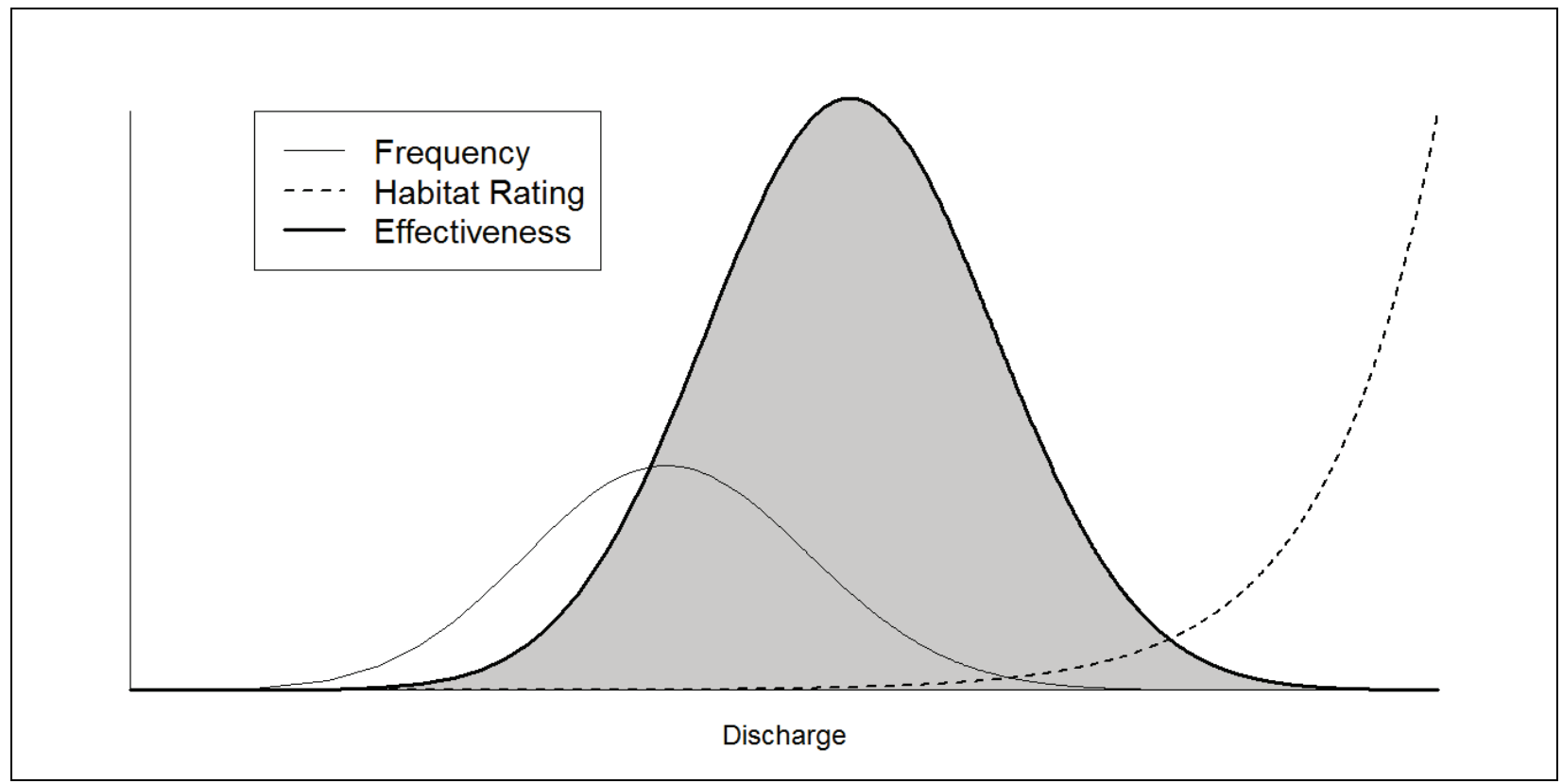

Figure 4. Conceptual depiction of effectiveness analysis (i.e., magnitude-frequency analysis).

RESULTS AND DISCUSSION: Simulations of environmental flow scenarios resulted in different types of hydrologic alteration for each of the three strategies (AMF, MMF, POF). Impacts to the discharge time series on flow magnitude were noticeably different between minimum flow strategies and percentage-based strategy, even at similar amounts of total withdrawal. The minimum flow approaches led to periods of "flat-lining" (Figure 5, top left), where modeled discharge reaches the minimum flow, set as the lower allowable limit in the model, whereas the POF approach maintained variability throughout the simulation, not being 
limited by a pre-determined minimum flow (Figure 5, top right). In addition to changes in river hydrographs, the strategies led to different withdrawal volumes in each of the 60 years simulated (Figure 5, bottom).

Hydraulic and habitat simulations provided a mechanism to construct habitat rating curves for each of the four types of habitat assessed here (total, shallow-fast, deep-fast, and shallow-slow) (Figure 6). As expected, total habitat increases with increasing discharge (Figure 6). However, the distribution of habitat types changes dramatically over the range of discharges simulated. In particular, shallow-fast habitat appears only during a narrow band of discharges and represents a small portion of the total habitat, a notable outcome given the disproportionately high biodiversity of these "shoal" conditions (Travnichek and Maceina 1994). The mosaic of habitats is, thus, differentially affected with changes in the environmental flow regime.

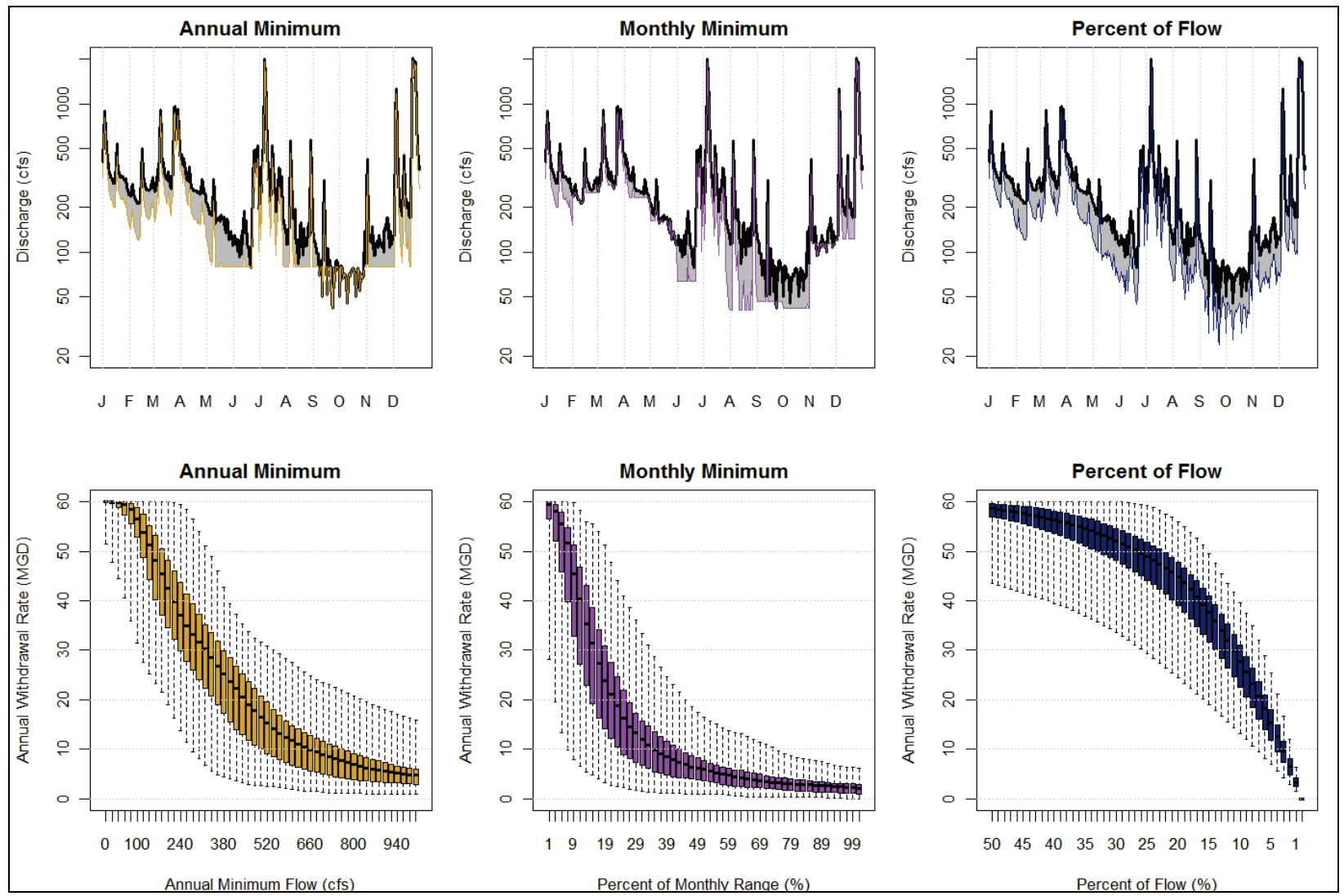

Figure 5. Effects of environmental flow alternatives, from left to right: AMF, MMF and POF scenarios. (Top) Example of hydrographic effects for the sample year 1941. All flow management alternatives provide similar levels of average water withdrawal (i.e., 55.5, 55.4, and 55.5 MGD, respectively). Thick black lines represent unaltered discharge, thin colored lines represent the altered hydrograph for this scenario, and grey represents water withdrawn to Bear Creek reservoir. (Bottom) Variability in municipal water withdrawal over a range of environmental flow scenarios for the entire period of record. Each box represents the range of annual withdrawal rates across the 60 -year simulation period, and the $x$-axis represent the flow management scenarios described above. 


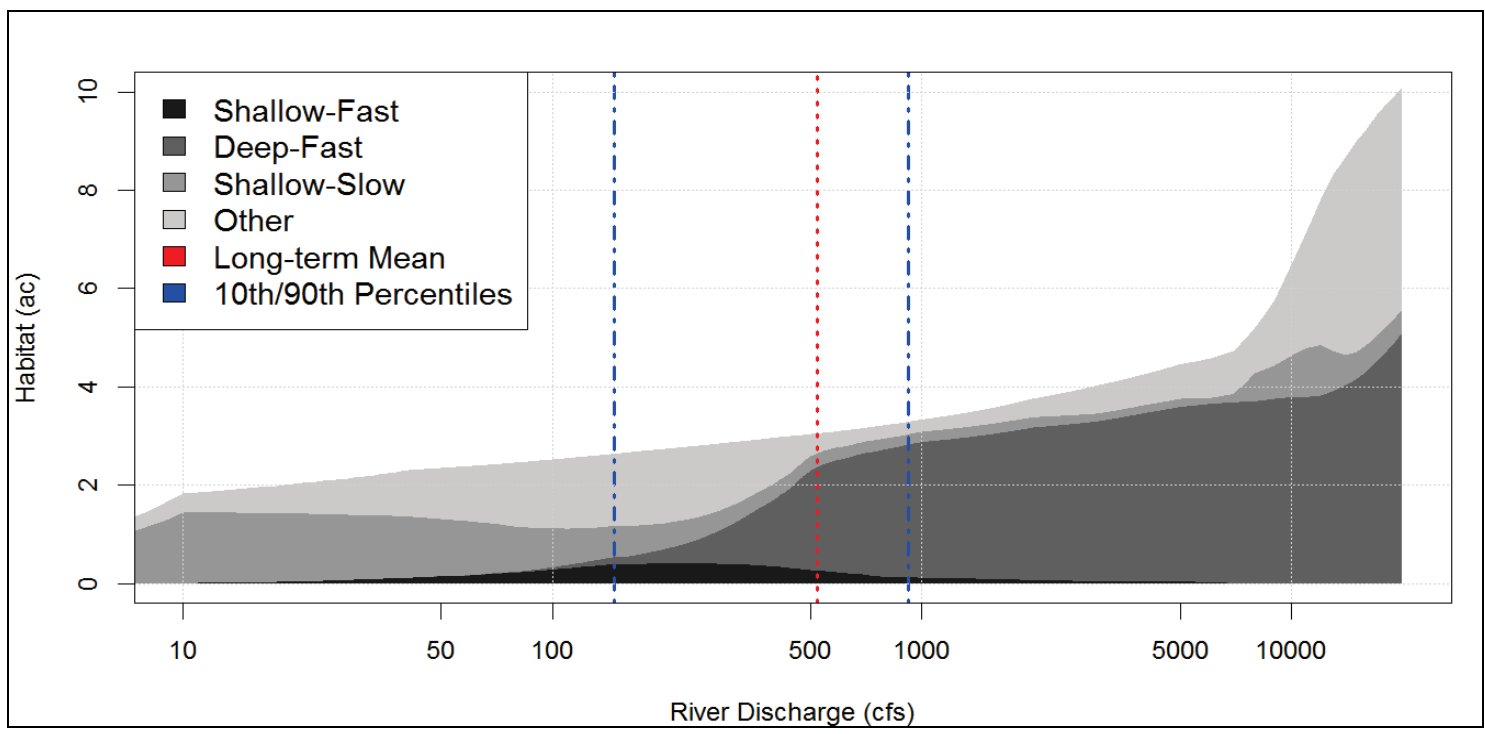

Figure 6. Cumulative habitat rating curves over the range of discharges observed.

These simulations provide a mechanism to assess trade-offs between municipal water supply and habitat provision under the three environmental flow schemes (AMF, MMF, POF). While the average municipal water yield across the scenarios is of interest to many applications, municipal water suppliers must often focus on the outcome with the greatest potential for societal impact, the minimum water yield across the 60-year simulation. This represents the worst case scenario for water supply outcomes, and thus, is used in assessing trade-offs with habitat (Figure 7). The three environmental flow alternatives are compared on an equal withdrawal basis in an effort to find the most efficient alternative. For instance, for any given level of water withdrawal, which alternative provides the most habitat, and for any given level of habitat, which alternative provides the most water for withdrawal? From the perspective of total available habitat and deep-fast habitat, both the average discharge output and the frequency-weighted output indicate the percent-of-flow approach to be the most efficient. However, results are mixed for the shallow-fast and shallow-slow habitats with all three environmental flow alternatives indicating differing efficiencies at different withdrawal rates.

Key differences emerge in the findings based on average annual discharge (Figure 7 top) or a magnitude-frequency analysis (Figure 7 bottom). First, total habitat is consistently over-predicted by the average discharge method. This is an expected outcome given that flow frequency distributions are often highly skewed (not normally distributed), which leads to a mean discharge much greater than the median discharge (e.g., $521 \mathrm{cfs}$ vs. $350 \mathrm{cfs}$ for the Middle Oconee River). By combining the probability of each flow magnitude under the three flow scenarios with habitat quantity (through effectiveness analysis), the effect of a naturally non-normally distributed flow frequency curve is incorporated into the habitat quantity calculations, enabling more accurate assessment of changing habitat quantity with increasing withdrawal rates. Second, only tracking average discharge can mask nuanced effects associated with alternative environmental flow regimes. For instance, the shallow-fast habitat assessments with magnitude-frequency analysis show a non-monotonic response, potentially due to changes in low flows as well as central tendencies. Third, the relative ranking of environmental flow strategies shifts depending on whether average or frequency-weighted conditions are used. 


\section{ERDC/TN EMRRP-SR-85}

\section{March 2019}
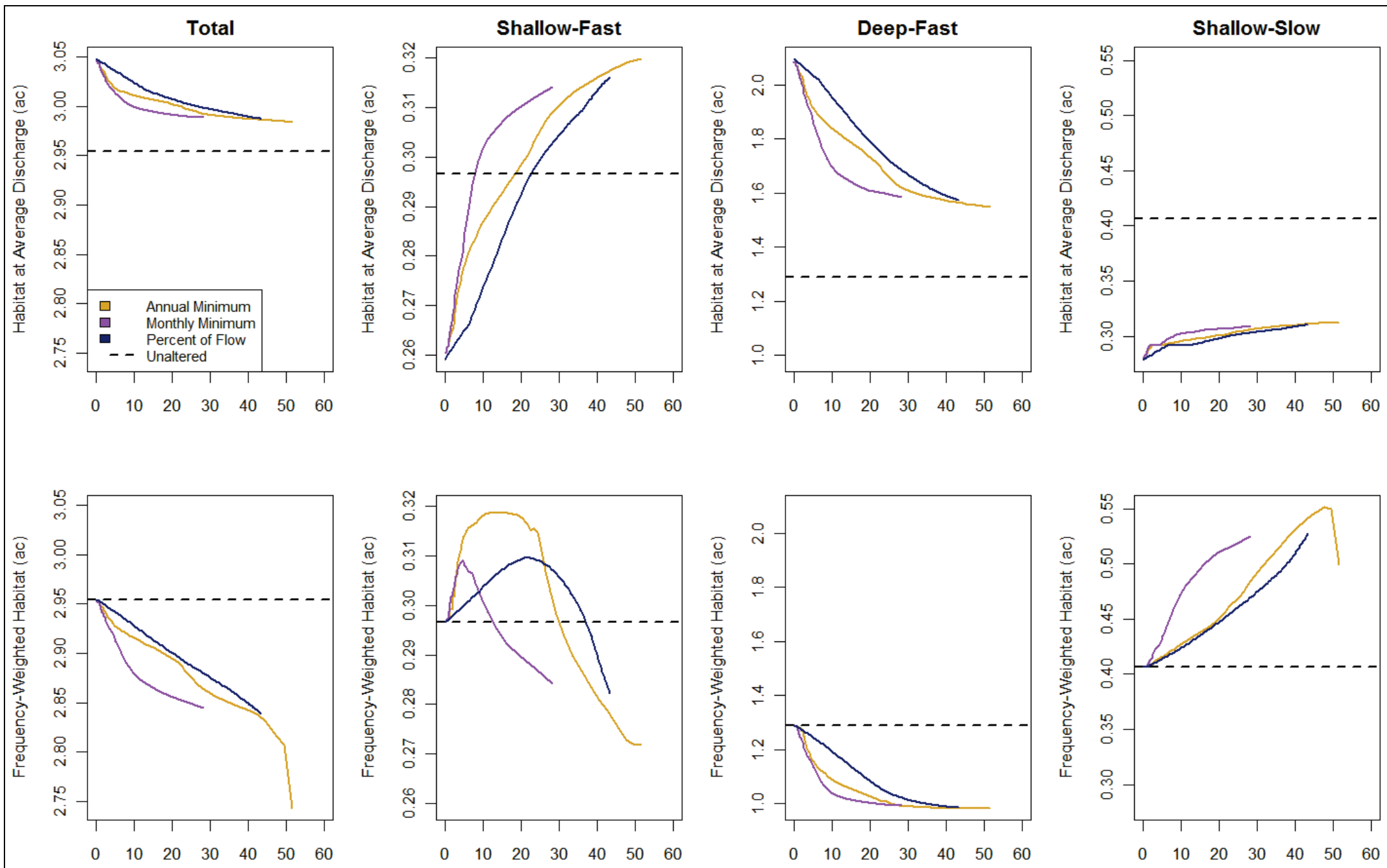

Minimum Annual Withdrawal Rate (MGD)

Minimum Annual Withdrawal Rate (MGD)

Minimum Annual Withdrawal Rate (MGD)

Minimum Annual Withdrawal Rate (MGD)

Figure 7. Comparison of environmental flow alternatives across total wetted habitat and three distinct habitat types. Notably, the permitted withdrawal rate of 60 MGD cannot be reliably supplied by any operational scheme (i.e., the minimum annual withdrawal is always less than 60 MGD), and some scenarios cannot reliably supply more than 30 MGD. (top) Habitat computed at average discharge. (bottom) Habitat computed as a frequency-weighted quantity using effectiveness analysis. 
CONCLUSION: This study addressed two primary objectives. First, the team sought to demonstrate a suite of methods for comparing simple environmental flow alternatives and developing flow thresholds which apply a common approach to habitat analyses. Three existing families of methods were coupled to accomplish this objective. Hydrologic simulation is a common tool for examining potential consequences of operational changes at water infrastructure (e.g., Klipsch and Hurst 2013, McKay 2015) and watershed-scale planning (e.g., LaFontaine et al. 2015). Habitat analysis has a deep history in water resource management and environmental flow analysis, which includes a suite of techniques such as the Physical Habitat Simulation (PHABSIM), Instream Flow Incremental Methodology (IFIM), the Riverine Community Habitat Assessment and Restoration Concept (RCHARC), the Ecosystem Functions Model (HEC-EFM), and a variety of other methods (reviewed in McKay 2013). Magnitudefrequency analysis (Wolman and Miller 1960; Doyle et al. 2005) then provided a mechanism to synthesize outputs from the hydrologic simulations and the habitat models. Simple forms of these techniques using ad hoc hydrologic simulation (McKay 2015; McKay et al. 2016), generalized habitat criteria (Freeman et al. 1997), and a basic form of effectiveness analysis (Doyle et al. 2005), were coupled to create a useful analytical framework easily adaptable to other study sites. Currently, standardized USACE platforms can perform many of these functions (e.g., HEC-ResSim, Klipsch and Hurst 2013, HEC-EFM, Hickey and Fields 2009).

The second major objective was to examine the role of variability in setting flow management thresholds by comparing environmental flow recommendations developed using typical river levels (i.e., long-term averages) with those developed using a frequency-weighted approach (i.e., effectiveness analysis). Environmental flow and river restoration analyses often use average discharge conditions when assessing the benefits of restoration actions. However, this analysis shows that average conditions are not necessarily indicative of the effects of environmental management actions. The effectiveness analysis approach applied here addresses some (not all) of these deficiencies by incorporating the range of variability in discharge along with the event frequency. However, timing, duration, and rate-of-change of flows can also be crucial to ecological functions (Poff et al. 1997) and were ignored in this analysis.

This study contributes to a growing body of information about the effects of river flow regimes on the Middle Oconee River ecosystem (e.g., Nelson and Scott 1962, Grubaugh and Wallace 1995, Katz and Freeman 2015, McKay 2015, McKay et al. 2016). A number of these studies have focused on the consequences of different environmental flow alternatives, and this body of evidence suggests that overall, percent-of-flow approaches appear to have fewer ecological impacts than minimum flow approaches. However, results shift slightly depending on the process investigated, and in some scenarios minimum flow approaches are functionally equivalent to percent-of-flow approaches (McKay 2015, McKay et al. 2016). Although some outcomes are highly sensitive to changes in low flow conditions, many of the species in the river exhibit remarkable resilience to drought and low flows (Katz and Freeman 2015). Practical issues like multi-purpose operation, constrained outlet structures, or reservoir storage should also be considered when designing flow regimes, and combined approaches (e.g., minimum flow and percent-of-flow approach) may be important to accommodate these constraints during different seasons or for different objectives. 


\section{ERDC/TN EMRRP-SR-85}

March 2019

In order to take into account the impact of development on the environment, it is essential to study flow regimes and trade-offs involved in water management. Here, a new coupling of analytical techniques is presented which helps incorporate natural variability into environmental flow studies. In doing so, the importance of hydrologic variability is demonstrated, not only relative to ecological outcomes, but also relative to water management decision making.

ADDITIONAL INFORMATION: Research presented in this TN was developed under the Ecosystem Management and Restoration Research Program (EMRRP) and Georgia Water Resources Institute (GWRI) Program. The USACE Proponent for the EMRRP Program is Ms. Mindy Simmons and the Technical Director is Dr. Al Cofrancesco. Dr. Bruce Pruitt and Mr. Lucas Montouchet collected 2013 survey data, and Mr. Tom Prebyl assisted with geospatial analyses. Ms. Sarah Miller (ERDC-EL), Mr. Chirs Haring (ERDC-CHL), Mr. Mick Porter (USACE Albuquerque District), Mr. Justin McDonald, and Mr. Brian Zettle (USACE Mobile District) graciously reviewed this document. For additional information, contact Dr. S. Kyle McKay (601-415-7160, Kyle.McKay@usace.army.mil). This TN should be cited as follows:

Bhattacharjee N. V., J. R. Willis, E. W. Tollner, and S. K. McKay. 2019. Habitat Provision Associated With Environmental Flows. EMRRP Technical Notes Collection. ERDC/TN EMRRP-SR-85. Vicksburg, Mississippi: U.S. Army Engineer Research and Development Center.

\section{REFERENCES}

Arthington, A. H., S. E. Bunn, N. L. Poff, and R. J. Naiman. 2006. The challenge of providing environmental flow rules to sustain river ecosystems. Ecological Applications 16(4):1311-1318. |https://doi.org/10.1890/10510761(2006)016[1311:TCOPEF]2.0.CO;2.

Bain, M. B. 1995. Habitat at the local scale: multivariate patterns for stream fishes. Bulletin Francais de la Peche et de la Pisciculture (France). ISSN :0767-2861.

Bowen, Z. H., M. C. Freeman, and K. D. Bovee. 1998. Evaluation of generalized habitat criteria for assessing impacts of altered flow regimes on warmwater fishes. Transactions of the American Fisheries Society 127(3), 455-468. https://doi.org/10.1577/1548-8659(1998)127<0455:EOGHCF>2.0.CO;2.

Brunner, G. W. 2001. HEC-RAS River Analysis System: User's Manual. Vicksburg, MS: U.S. Army Corps of Engineers (USACE), Institute for Water Resources (IWR), Hydrologic Engineering Center (HEC).

Campana, P., J. Knox, A. Grundstein, and J. Dowd. 2012. The 2007-2009 drought in Athens, Georgia, United States: A climatological analysis and an assessment of future water availability. Journal of the American Water Resources Association (JAWRA) 48(2):379-390. |https://doi.org/10.1111/j.1752-1688.2011.00619.x.

Chow, V. T. 1959. Open Channel Hydraulics. New York: McGraw-Hill.

Doyle, M. W., Stanley E.H., Strayer D.L., Jacobson R.B., and Schmidt J.C. 2005. Effective discharge analysis of ecological processes in streams. Water Resources Research 41 (W11411), doi:10.1029/2005WR004222.

Dudgeon, D., A. H. Arthington, M. O. Gessner, Z. I. Kawabata, D. J. Knowler, C. Lévêque, R. J. Naiman, A. H. Prieur-Richard, D. Soto, M. L. Stiassny, and C. A. Sullivan. 2006. Freshwater biodiversity: importance, threats, status and conservation challenges. Biological Reviews 81(2):163-182. https://doi.org/10.1017/S1464793105006950.

Freeman, M. C., Z. H. Bowen, and J. H. Crance. 1997. Transferability of habitat suitability criteria for fishes in warmwater streams. North American Journal of Fisheries Management 17(1):20-31. |https://doi.org/10.1577/1548-8675(1997)017<0020:TOHSCF>2.3.CO;2. 
Grubaugh, J. W., and Wallace J.B. 1995. Functional structure and production of the benthic community in a Piedmont river: 1956-1957 and 1991-1992. Limnology and Oceanography 40(3):490-501. |https://doi.org/10.4319/lo.1995.40.3.0490.

Hickey, J., and W. Fields W. 2009. HEC-EFM Ecosystem Functions Model, Quick Start Guide. Vicksburg, MS: U.S. Army Corps of Engineers (USACE), Institute for Water Resources (IWR), Hydrologic Engineering Center (HEC).

Jackson, R. B., S. R. Carpenter, C. N. Dahm, D. M. McKnight, R. J. Naiman, S. L. Postel, and S. W. Running. 2001. Water in a changing world. Ecological Applications 11(4):1027-1045. https://doi.org/10.1890/10510761(2001)011[1027:WIACW]2.0.CO;2.

Jowett, I. G. 1997. Instream flow methods: A comparison of approaches. River Research and Applications 13(2): 115-127. https://doi.org/10.1002/(SICI)1099-1646(199703)13:2<115::AID-RRR440>3.0.CO;2-6.

Katz, R. A., and F. C. Freeman. 2015. Evidence of population resistance to extreme low flows in a fluvial-dependent fish species. Canadian Journal of Fisheries and Aquatic Sciences 72(11):1776-1787. https://doi.org/10.1139/cjfas-2015-0173.

Klipsch, J. D., and M. B. Hurst. 2013. HEC-ResSim Reservoir System Simulation: User's Manual. Version 3.1. Davis, California: Army Corps of Engineers (USACE), Institute for Water Resources (IWR), Hydrologic Engineering Center (HEC).

LaFontaine, J. H., L. E. Hay, R. J. Viger, R. S. Regan, and S. L. Markstrom. 2015. Effects of climate and land cover on hydrology in the southeastern U.S.: Potential impacts on watershed planning. Journal of the American Water Resources Association (JAWRA) 51(5):1235-1261. https://doi.org/10.1111/1752-1688.12304.

Mathews, R., and B. Richter. 2007. Application of the indicators of hydrologic alteration software in environmental flow setting. Journal of the American Water Resources Association (JAWRA) 43(6):1400-1413. https://doi.org/10.1111/j.1752-1688.2007.00099.x.

McKay, S. K. 2013. Alternative Environmental Flow Management Schemes. ERDC TN-EMRRP-SR-46. Vicksburg, Mississippi. U.S. Army Engineer Research and Development Center.

McKay, S .K. 2015. Quantifying tradeoffs associated with hydrologic environmental flow methods. Journal of the American of the American Water Resources Association (JAWRA) 51(6):1508-1518. https://doi.org/10.1111/1752-1688.12328.

McKay, S. K., M. C. Freeman, and A. P. Covich. 2016. Application of effective discharge analysis to environmental flow decision-making. Environmental Management 57(6):1153-1165.

Nelson, D. J., and D. C. Scott. 1962. Role of detritus in the productivity of a rock-outcrop community in a Piedmont stream. Limnology and Oceanography 7 396-413. https://doi.org/10.4319/lo.1962.7.3.0396.

Northeast Georgia Regional Commission. 2011. Northeast Georgia Plan 2035: Regional Assessment. (Accessed 30 August 2016). http://www.negrc.org/user_files/1326901800_RegAssessmentFINAL.pdf.

Poff, N. L., J. D. Allan, M. B. Bain, J. R. Karr, K. L. Prestegaard, B. D. Richter, R. E. Sparks, and J. C. Stromberg. 1997. The natural flow regime. Bioscience 47(11):769-784. doi: 10.2307/1313099.

Poff, N. L. 2009. Managing for variability to sustain freshwater ecosystems. Journal of Water Resources Planning and Management 135(1):1-4. https://doi.org/10.1061/(ASCE)0733-9496(2009)135:1(1).

R Development Core Team. 2012. R: A language and environment for statistical computing. Vienna, Austria: R Foundation for Statistical Computing, www.R-project.org.

Richter, B. D. 2010. Re-thinking environmental flows: From allocations and reserves to sustainability boundaries. River Research and Applications 26(8):1052-1063. https://doi.org/10.1002/rra.1320.

Richter, B. D., M. M. Davis, C. Apse, and C. Konrad. 2011. A presumptive standard for environmental flow protection. River Research and Applications 28(8): 1312-1321. https://doi.org/10.1002/rra.1511.

Sabo, J. L., and D. M. Post. 2008. Quantifying periodic, stochastic, and catastrophic environmental variation. Ecological Monographs 78(1):19-40. https://doi.org/10.1890/06-1340.1. |https://doi.org/10.1890/06-1340.1. 


\section{ERDC/TN EMRRP-SR-85}

\section{March 2019}

Strayer, D. L., and D. Dudgeon. 2010. Freshwater biodiversity conservation: recent progress and future challenges. Journal of the North American Benthological Society Freshwater Benthic Science 29(1):344-358. https://doi.org/10.1899/08-171.1.

Tharme, R. E. 2003. A global perspective on environmental flow assessment: Emerging trends in the development and application of environmental flow methodologies for rivers. River Research and Applications 19(5-6):397442. https://doi.org/10.1002/rra.736.

Travnichek, V. H., and M. J. Maceina. 1994. Comparison of flow regulation effects on fish assemblages in shallow and deep water habitats in the Tallapoosa River, Alabama. Journal of Freshwater Ecology 9(3):207-216. https://doi.org/10.1080/02705060.1994.9664888.

Upper Oconee Regional Water Planning Council. 2011. Upper Oconee Regional Water Plan. (Accessed 30 August 2016). http://www.upperoconee.org/documents/UOC_Adopted_RWP.pdf.

Vogel, R. M., J. Sieber, S. A. Archfield, M. P. Smith, C. D. Apse, and A. Huber-Lee. 2007. Relations among storage, yield, and instream flow. Water Resources Research 43(5). https://doi.org/10.1029/2006WR005226.

Wheatcroft, R. A., M. A. Goni, J. A. Hatten, G. B. Pasternack, and J. A. Warrick. 2010. The role of effective discharge in the ocean delivery of particulate organic carbon by small, mountainous river systems. Limnology and Oceanography 55(1):161-171. https://doi.org/10.4319/lo.2010.55.1.0161.

Wolman, M. G., and J. P. Miller. 1960. Magnitude and frequency of forces in geomorphic processes. Journal of Geology 68(1):54-74. https://doi.org/10.1086/626637.

NOTE: The contents of this technical note are not to be used for advertising, publication, or promotional purposes. Citation of trade names does not constitute an official endorsement or approval of the use of such products. 